\title{
Sob o signo da iconologia: uma exploração do livro Saturno e a melancolia, de R. Klibansky, E. Panofsky e F. Saxl
}

Sérgio Alcides

primeira vista, espanta que Italo Calvino tenha evocado a melancolia
justamente na conferência sobre a "leveza", preparada para as Norton Lectures e publicada postumamente em Seis propostas para o próximo milênio. Não é o pesar a principal característica dos melancólicos? Não para Calvino, que apontava para um "sintoma" bem menos categórico e sombrio: a "gravidade sem peso", uma qualidade que o escritor recomendou ao futuro. "É aquela relação particular entre melancolia e humor, que Klibansky, Panofsky e Saxl estudaram em Saturn and Melancholy" - escreveu [Calvino: 1985, 32]. O mais surpreendente, para quem conhece a obra citada, é que ela não trata especificamente dessa relação, como a afirmação do conferencista pode fazer supor. Num livro de 700 páginas, Calvino foi direto a um tema apenas esboçado, em dois ou três parágrafos [Klibansky et al:: 1964, 380-1].

A rápida menção a esse livro de "estudos históricos e filosóficos" é reveladora de uma certa atitude perante o conhecimento inteiramente diversa da que os autores citados manifestavam. Para Calvino, a velha distinção entre vita contemplativa e vita activa não fazia nenhum sentido; as conferências de 1985 são a maior prova, ao se interrogarem sobre os "valores ou qualidades ou especificidades da literatura" que poderão colaborar num programa ético para os desdobramentos da era pós-industrial [Calvino: 1985, 11]. Raymond Klibansky (1905-1997), Erwin Panofsky (1892-1968) e Fritz Saxl (1890-1948), cada um em seu campo, trabalharam numa perspectiva mais convencional - embora conscientes da medida de ação implicada nos estudos acadêmicos e preocupados em estabelecer parâmetros

Topoi, Rio de Janeiro, set. 2001, pp. 131-173. 
mais seguros para suas disciplinas, contra o diletantismo erudito que era um risco permanente em suas geraçóes.

Muitos argumentos históricos e filosóficos compóem o plano geral de Saturno e a melancolia; a relação com o desenvolvimento do humorismo na modernidade é apenas um deles. Este, entretanto, era o que mais interessava a Calvino, diante das questões que ele pretendia enfrentar na sua série de conferências. Nenhum outro compromisso o impediu, portanto, de ir "direto ao ponto". Sob esse aspecto, é preciso reconhecer que o escritor foi certeiro: em meio ao vastíssimo campo de conhecimentos e especulações contidos no livro, soube encontrar precisamente o comentário que iluminaria ainda mais sua apologia da leveza. Com essa encantadora agilidade, aliás, Calvino dava exemplos de pelo menos três das seis propostas: "leveza" na argumentação, "rapidez" nas considerações e "exatidão" na escolha, mas sem perder de vista a "multiplicidade" das conexões e a "consistência" do resultado; quanto à "visibilidade", bem, esta seria testada na performance do conferencista diante de seu público, a velha elocutio da retórica clássica, se a morte não viesse antes. ${ }^{1}$

Klibansky, Panofsky e Saxl também tinham um "ponto" muito específico, que pretendiam atacar: a gravura Melencolia I, feita por Albrecht Dürer em 1514 - uma personificação alegórica sobrecarregada de simbologia e mistério. Num trabalho que se estendeu por cinco décadas, os autores se sentiram obrigados a percorrer a longa trajetória da idéia de melancolia desde a Antigüidade até os tempos modernos, num enfoque multifacetado que deveria passar necessariamente pela filosofia, a teologia, a astrologia, a medicina, a poesia e as artes visuais. Na arquitetura do livro, todos os conhecimentos mobilizados pelos autores em cada uma dessas correntes (sempre entrecruzadas) vêm convergir na famosa gravura, como "equipamento" indispensável à sua interpretação, ou seja, à descoberta de seu significado histórico-cultural "num sentido mais profundo", conforme o método iconológico teorizado por Panofsky [1939, 3-17]. Depois desse tour-de-force dos pesquisadores, a obra de Dürer se converte no símbolo mais eloqüente de uma nova concepção do homem superiormente dotado, especificamente moderna, que em finais do século XVIII desaguaria no conceito de "gênio": aquele indivíduo que é capaz de elevar o seu en- 
tendimento a esferas inacessíveis aos demais mortais, ao preço do maior isolamento e dos piores infortúnios, sob o fardo de seu próprio temperamento instável, desordenado e sempre insatisfeito, de quem não só abandonou a segurança das doutrinas religiosas mas ainda busca em si mesmo uma perfeição super-humana, inatingível.

Já se percebe a estreita relação entre esse projeto quase enciclopédico e a iconologia, nos termos postos por Panofsky em sucessivas elaborações teóricas [1932, 1939, 1955]. Com esse novo método fundamentalmente hermenêutico, o historiador da arte se apropriava da filosofia neokantiana de Ernst Cassirer e da sociologia do conhecimento de Karl Mannheim para vencer os impasses teóricos e epistemológicos da tradição germânica de estudos sobre a história da arte, às voltas com as noções de Zeitgeist e Weltanschaunng, que se impuseram no século XIX a partir da filosofia de Hegel e das obras de historiadores e teóricos como Jacob Burckhardt e Wilhelm Dilthey. ${ }^{2} \mathrm{O}$ pressuposto jamais discutido nessa tradição era a preexistência de uma totalidade transcendental que se elegia como objeto privilegiado de qualquer investigação no campo das humanidades - significativamente denominado, em alemão, Geisteswissenschaften. ${ }^{3}$ Assim, uma gravura de inícios do século XVI podia ser tomada como via simbólica de acesso à contemplação desse todo, esclarecendo um conjunto de características determinantes de um certo recorte espaço-temporal, universalmente válidas. O curioso é que o aporte que Panofsky apresentou nos anos 1930 parecia reconhecer as dificuldades decorrentes dessa concepção geral, com seus a prioris oitocentistas, mas evitava a todo custo uma ruptura; ao contrário, o teórico preferiu buscar apoio em "corretivos objetivos" [ $c f$. Panofsky: $1932,249]$, conceitos mediadores ou relativizantes, que assegurassem a manutenção dos a prioris universalizantes diminuindo ou "regulando" as distorções deles decorrentes. O conceito de volição artística (Kunstwollen), captado em Riegl e reformulado a partir de Mannheim nos anos 1920, operava nessa direção: em Panofsky, aparecia como um meio de interpretação unificador, sinóptico e formativo que reconciliaria a teoria da arte à sua história, a partir dos modelos cognitivos que condicionavam historicamente a produção das obras de arte [ $c f$. J. Hart: 1993, 549]. A composição entre os conceitos de forma simbólica (Cassirer) e volição artística 
(Riegl), na grade hermenêutica da interpretação em três níveis (Mannheim), permitiria uma abordagem segura da significação mais transcendente de uma obra de arte, com um salto do particular ao universal e a respectiva revelação dos princípios mais fundamentais da visão de mundo em ação numa certa época, num certo lugar.

A aplicação desse esquema, apesar de sua sofisticação teórica e conceitual, raramente se fez sem despertar uma série de críticas, caso a caso, mesmo depois de a iconologia se tornar um paradigma hegemônico nos Estados Unidos e na Inglaterra, a partir dos anos 1940. A descida aos detalhes parecia sempre abrir um espaço ou desvão de controvérsias que incidia principalmente sobre a passagem de um nível para outro, quer dizer, ou da "descrição pré-iconográfica" para a "análise iconográfica" ou desta para a "interpretação iconológica” — preservando-se o a priori inamovível. Ou se questionava a seleção do material iconográfico, ou o tipo de "intuição sintética” que orientou o avançar das hipóteses, ou mesmo o resultado da operação final. ${ }^{4}$

A partir de meados dos anos 1960, no entanto, começaram a ganhar força as críticas que visavam de modo mais direto o fundo teórico do programa iconológico. Um desses críticos, Carlo Ginzburg, chegou a levantar a suspeita de que o próprio Panofsky, em seus últimos trabalhos, já não levava a iconologia tão a sério [Ginzburg: 1966, 68]. Mesmo um historiador da arte como E. H. Gombrich, que pode ser filiado à mesma "família" de Panofsky, afastou o transcendentalismo dos fundamentos de sua extensa obra, rejeitando a noção de "estilo" como expressão de uma "personalidade coletiva" ou como um "sistema integralmente expressivo". ${ }^{5}$ Outra alegação freqüente dos críticos é que a iconologia seria um método de aplicabilidade restrito a obras de arte renascentistas; vai neste sentido a acusação de "italocentrismo" a Panofsky [ $c f$. Moxey: 1995, 776]. Também têm encontrado ampla difusão as críticas ao universalismo implícito no paradigma iconológico, bem como à abordagem centrada na idéia da obra de arte, ou seja: restrita à produção e negligente quanto aos aspectos recepcionais das diferentes apropriações sociais das obras de arte ao longo do tempo. Ambas as características tendem a "apagar" os conflitos sociais que demarcam o campo de produção, recepção e circulação das artes nos 
recortes dados. Há críticos, ainda, insatisfeitos com o método panofskiano por privilegiar o "conteúdo" e a significação em detrimento da forma ou mesmo da indissociabilidade desses aspectos [cf. Diers: 1995, 63].

À medida que essas críticas se avolumavam, o Panofsky já estabelecido e consagrado da Universidade de Princeton se dispunha cada vez menos a discutir teoria, até porque esse tipo de discussão parecia impensável onde a própria História da Arte, como domínio disciplinar, ainda precisava ser implantada e consolidada. Para tanto, o mestre se contentava em apresentar versões simplificadas das reflexões teóricas que desenvolvera na Alemanha, nos anos 1920 e nos inícios da década de $1930 .{ }^{6}$ Nessa primeira fase, Panofsky teorizava intensamente, e sob cerrada pressão de seus interlocutores e alvos; de um lado, os seguidores da tradição mais formalista de Wölfflin; de outro, as correntes filosóficas que, mesmo na Alemanha, começavam a trazer alternativas ao transcendentalismo. ${ }^{7}$

O problema mais complexo apontado pelos críticos de então - e retomado mais de 30 anos depois por Ginzburg - era o risco de a perspectiva universalizante guiar previamente a interpretação de uma obra de arte em particular, num ciclo vicioso que, grosso modo, funcionaria assim: uma pintura específica pode ser entendida a partir do nosso acervo de conhecimentos sobre a visão de mundo geral determinante em seu tempo; esta, por outro lado, pode ser conhecida a partir da análise daquela mesma obra de arte. A saída de Panofsky e seu grupo foi redargüir aos críticos que o aparente ciclo vicioso era, na verdade, um circulus methodicus, no qual cada elemento (o específico e o geral) incessantemente esclarece o outro em progressão contínua [Panofsky: 1932, 250]. É no contexto desse debate que o método iconológico canonicamente apresentado em 1939 e 1955 começa a ser formulado, já com a grade tríplice de Mannheim [idem, p. 251] e com os "corretivos objetivos", como os conceitos de Kunstwollen e Typus.

Infelizmente, a transferência de Panofsky para os Estados Unidos, em 1934, interrompeu esse debate, notando-se na obra do grande historiador uma mudança de inflexão nada desprezível. Essa reviravolta do destino faz de Saturno e a melancolia um livro particularmente interessante, cuja "história” é tão turbulenta que parece imitar o próprio século XX. Trata-se de 
uma obra atravessada pela ascensão do nazismo e pela diáspora de seus autores, judeus de formação visceralmente alemã, espalhados por países estrangeiros. O plano inicial foi traçado em Hamburgo, em meados dos anos 1920, no calor do debate teórico que resultaria na sistematização da iconologia. Mas a versão final só chegou a ser publicada em 1964, em Londres e Nova York, muito tempo depois de Panofsky abandonar o antigo fervor teorizante.

O objetivo deste trabalho é examinar Saturno e a melancolia à luz desse "mapa" teórico, considerando sua "história" e as diferentes trajetórias de seus autores, avançando algumas hipóteses sobre suas motivações e impasses e, ainda, verificando sua relação com o método iconológico. Tendo em vista minhas preocupações mais específicas em meu campo de pesquisa - a relação entre cultura letrada e melancolia no início dos tempos modernos — também será útil, por fim, sistematizar minha própria percepção da obra, ressaltando os pontos que permanecem iluminadores, apesar de possíveis inadequações teóricas e metodológicas.

\section{1}

A versão final de Saturno e a melancolia divide-se em quatro longas partes. A primeira é um painel histórico da noção de melancolia na filosofia e nas artes medicinais da Antigüidade e da Idade Média. A segunda investiga a imagem de Saturno (o deus e o planeta) na mitologia, nas artes e na astrologia. A terceira se dirige predominantemente ao Renascimento italiano diante dos mesmos temas. A quarta, finalmente, debruça-se sobre a gravura Melencolia I, de Dürer, e seu "legado artístico".

A enigmática gravura de 1514 só é mencionada en passant, duas ou três vezes, nas três primeiras partes. Mesmo assim, quando os autores iniciam a análise detida da obra, a primeira impressão que se tem é de estar no centro de um vasto projeto. Enfim se esclarece a conexão entre as partes antecedentes, com seus vários capítulos; retrospectivamente, o livro ganha então um feitio de narrativa épica: conta a história de um longo détour, cheio de idas e vindas, desvios e retrocessos, entre os Bálcãs e a Baviera, com passagens pelo Norte da África, a Arábia e a Península Ibérica, e depois de uma inesquecível estada em Florença. O herói - aquele que ultra- 
passou o métron, em sua desmedida — só se revela inteiramente nas últimas páginas da terceira parte:

O advento da nova consciência humanista se fez, portanto, numa atmosfera de contradição intelectual. No momento mesmo em que alcançava um lugar na ordem do universo, o homo literatus autônomo se via sacudido entre dois extremos: o da auto-afirmação, por vezes exaltada até a hýbris, e o da dúvida sobre si próprio, que podia atingir o desespero; e foi ao experimentar essa dualidade que o homo literatus descobriu um novo modelo intelectual, que refletia essa desarmonia ao mesmo tempo trágica e heróica: o modelo do "gênio moderno". A essa altura, constatamos que o gênio criador não poderia se reconhecer senão sob o signo de Saturno e da melancolia [Klibansky et al.: 1964, 395-6].

O afã desse herói moderno foi buscar "lugar na ordem do universo", mas não um lugar sobredeterminado pelas correspondências da cosmologia tradicional, entre macro e microcosmos; o homo literatus aspirava à autonomia, ou seja, a regular-se a si próprio. Era um descomedimento; a melancolia foi a recompensa trágica, na perspectiva de Klibansky, Panofsky e Saxl. De um lado a auto-afirmação, de outro a autodepreciação, a exaltação e o desespero, a mania e a depressão: ao "gênio criador" era vetado o meiotermo, a justa medida.

Mas isso não lhe aconteceu de uma hora para outra, contingentemente; Saturno e a melancolia também narra a sua formação — Bildung — e a sua consagração final em Florença:

Somente o humanismo do Renascimento italiano soube reconhecer em Saturno e no homem de temperamento melancólico essa polaridade que, na verdade, estava implícita desde o início, mas só a intuição brilhante de [pseudo] "Aristóteles" e a perspicácia de santo Agostinho, aguçada pelo horror, puderam percebê-la [idem, 396].

Uma longa trajetória, portanto, estava por trás desse novo sujeito, remontando à Antigüidade clássica. Ressalte-se, porém, que o potencial de seu esplendor criativo e intelectual já estava presente "desde o início", tendo sido vislumbrado apenas ocasionalmente. Sente-se a influência de Jacob Burckhardt — não só o de Cultura do Renascimento na Itália, mas também o teórico que descreveu as "três potências" em ação na história: a Religião, 
o Estado e a Cultura; para ele, somente em períodos de predominância da Cultura, como o Renascimento, florescem os grandes homens de letras e do pensamento, assim como as obras de arte e arquitetura mais notáveis. A história de Saturno e a melancolia deveria então reconstituir todas as etapas dessa emergência, no seu contexto histórico-cultural, até configurar-se um certo equilíbrio de forças (históricas) que privilegiasse a criatividade e a autonomia intelectual dos grandes homens.

Esse ponto, agora compreendemos, é o télos do livro, nunca abertamente afirmado enquanto tal pelos autores, mas sempre presente ao longo da extensa narrativa. E o passo seguinte do nosso herói é a travessia dos Alpes, da Florença de Marsílio Ficino e Michelangelo até a Nuremberg de Albrecht Dürer.

A primeira parte do livro, intitulada "A noção de melancolia e sua evolução histórica” [Klibansky et al.: cit., 31-197], trata das primeiras aparições do herói melancólico, superiormente dotado para as artes e o pensamento, mas condenado à prostração do corpo e à aflição da mente. O livro se abre com uma breve exposição da doutrina dos quatro humores - o sangue, a bile amarela (cólera), a bile negra (melancolia) e a fleuma - e dos respectivos temperamentos a que cada um predispunha, caso predominasse sobre os demais: o sangüíneo, o colérico, o melancólico e o fleumático. Em seguida, os autores examinam mais detidamente dois vislumbres filosóficos do tema central de sua obra: primeiro, a teoria do "furor divino" no Fedro, de Platão; depois, o texto "Problema XXX, 1", atribuído a Aristóteles. Platão falava do aspecto furioso da exaltação espiritual mais elevada, ao passo que o peripatético dos Problemata, já no contexto da doutrina dos humores, apresentava a melancolia como "o mal dos heróis". A partir desses dois textos antigos, os autores seguem a trajetória da melancolia ao longo da Idade Média, primeiro na teologia e na filosofia moral, depois na medicina escolástica, ponto em que as contribuições árabes começam a ganhar maior relevo (em Constantino Africano, Avicena e Averróis, p. ex.). A exposição se encerra com um painel da "vulgarização" da doutrina humoral a partir do século XII.

Notável nessas primeiras etapas do percurso é o desenvolvimento de uma visão negativa da melancolia e suas afecçōes, em muitas correntes. Os 
teólogos cristãos condenavam a acídia (a melancolia dos monges) como conduta pecaminosa, por negligenciar a prática das virtudes. Teólogos como Guilherme de Conches e a extraordinária Hildegarda de Bingen, por exemplo, associavam o destempero da humanidade ao evento da Queda. Os médicos descreviam minuciosamente as várias predisposições patológicas provocadas pela bile negra, não raro ressaltando o aspecto moral. A ampla disseminação dessas caracterizações da melancolia e suas vítimas, em finais da Idade Média, fez com que os melancólicos fossem associados não só ao sofrimento pessoal e à irascibilidade, mas também a uma quantidade de vícios nocivos ao convívio social, como a inveja, a desconfiança e a avareza. A apologia do temperamento melancólico teria de esperar até o apogeu do movimento neoplatônico florentino, sobretudo a partir da obra do médico e astrólogo Marsílio Ficino, na passagem do século XV para o XVI.

Nos três "livros da vida" de Ficino já aparece consolidada a conexão entre a doutrina humoral e a astrologia, relacionando o humor melancólico aos influxos de Saturno. A segunda parte da obra de Klibansky, Panofsky e Saxl é a narrativa dessa consolidação, chamada "Saturno, astro da melancolia” [Klibansky et al.: cit., 201-347]. O primeiro capítulo expõe o processo de associação da figura de Saturno - o deus da Idade de Ouro, banido por seu filho Júpiter - a outro Saturno, o planeta mais elevado do sistema estelar, tal como ele era então conhecido e representado. A astrologia árabe é assim contraposta a tradições mitológicas e teológicas sobre essas duas figuras de Saturno, compondo lentamente o painel que foi legado pela Idade Média ao humanismo italiano. O segundo capítulo, finalmente, analisa um variado número de documentos iconográficos representando ora o deus Saturno, ora seus "filhos".

A terceira parte - "Melancolia poética' e 'Melancolia generosa” [Klibansky et al.: cit., 351-432] — investiga as condições poéticas e filosóficas que permitiram aos humanistas elevar a melancolia à condição de requisito (ou sacrifício) sublime à dignidade do homem. É o momento de confrontar as imagens estudadas na parte anterior com as fontes literárias coevas, tarefa cumprida no primeiro capítulo dessa parte. O segundo conduz diretamente à filosofia de Marsílio Ficino, com um título por si só bastante esclarecedor: "A glorificação da melancolia e de Saturno sob o 
neoplatonismo florentino e o nascimento da noção moderna de gênio" [idem, 389-432]. É então que os autores resenham a trajetória do pensamento de Ficino, descrevendo suas pesquisas neoplatônicas sobre a imortalidade da alma, com vistas a uma filosofia moral fundamentalmente profilática e terapêutica (sempre segundo a visão dos três autores), que pudesse amenizar as conseqüências malignas da bile negra atraindo a influência de planetas benignos, como Júpiter e Vênus. Ficino foi o primeiro a associar o "furor divino" descrito por Platão às considerações do peripatético "Problema XXX, 1" sobre a melancolia dos homens de entendimento superior. O neoplatônico florentino dizia que, por ser semelhante ao centro da terra, a bile negra induzia a alma a pesquisar "o centro das coisas singulares", elevando a compreensão humana às coisas mais altas, "no que ela está perfeitamente conforme Saturno, o mais alto dos planetas" [apud Klibansky et al.: cit., 412]. A dupla condição fisiológica e astrológica, portanto, aprofundava a separação entre a alma e o corpo, produzindo espíritos superiormente dotados para o sublime e a contemplação transcendental. Para Ficino, o corpo de tais entes geniais era apenas "semivivo": tratava-se então de aliviar as penas decorrentes do mecanismo natural e cosmológico da compensação trágica.

A quarta parte marca o ponto de chegada desse périplo: "Dürer" [cit., 435-664]. Toda uma argumentação entre a terceira e a quarta partes pretende dar conta da aclimatação transalpina de reflexos e disposições éticas do humanismo florentino. Os reinos germânicos de vésperas da Reforma teriam sido atingidos em cheio pela disseminação do neoplatonismo humanista, particularmente na visão ficiniana. Este, portanto, constituía o quadro geral que presidiu à composição da gravura Melencolia $I$.

Entretanto, Klibansky, Panofsky e Saxl admitem que o pensamento de Ficino serviu-se de um "guia" para atingir a Baviera: Cornélio Agrippa de Nettesheim teria sido esse "mediador predestinado" [cit., 547]. Em sua obra De occulta philosophia, ele reformulava os temas da "melancolia generosa" descrita por Ficino, dividindo seus benefícios e malefícios em três... (digamos) níveis, hierarquicamente diferenciados, conforme a elevação rumo ao sublime absoluto. $\mathrm{O}$ gênio melancólico podia restringir-se à imaginação criativa, guiando as mãos dos grandes artistas (melancholia imagi- 
nativa); podia dominar ainda a razão discursiva, orientando assim a ação brilhante na esfera política e moral (melancholia rationalis); e podia, finalmente, apossar-se também da mente intuitiva, atraindo os plenos poderes de Saturno - era a melancholia mentalis, uma prerrogativa dos grandes teólogos, poetas e filósofos, sublimes visionários.

Para Klibansky, Panofsky e Saxl, esse esquema ascensional tripartite era a principal concepção intelectual por trás de Melencolia I. Não só ele explicava a reunião, nessa gravura, das figuras alegóricas da melancolia e da geometria - a "fusão de dois mundos diferentes de pensamento e sentimento" [idem, 494]. A filosofia de Agrippa também esclarecia o significado do signo "I" acrescentado ao título: tratava-se da personificação gráfica da melancholia imaginativa, a primeira da escala hierárquica. Confrontada com a biografia de Dürer, essa interpretação batia com a angústia existencial vivida pelo artista nos anos que antecederam à Reforma. Melencolia I era de 1514; é também através do esquema de Agrippa que os autores de Saturno e a melancolia assinalarão a solução desse conflito simbolizada na série dos "quatro apóstolos", pintada por Dürer em meados da década de 1520, após a conversão do artista ao luteranismo: João era representado como um homem de temperamento sangüíneo; Pedro aparecia como colérico; Marcos, um fleumático; o melancólico era Paulo - o grande inspirador de Lutero, com a doutrina da justificação pela fé. Nele, portanto, não se via a expressão de grave renúncia e desesperança que a alegoria representada em 1514 aparentava; Paulo era representado por Dürer como um filho da melancholia mentalis, graças à qual era admitido às mais altas esferas do entendimento e da contemplação [idem, 574-583].

Completa-se assim a gesta heróica do homo literatus, no Renascimento, culminando com sua chegada à Alemanha de Dürer e Agrippa. O restante de Saturno e a melancolia trata do "legado artístico" da gravura de 1514, incluindo ainda alguns apêndices sobre aspectos particulares dessa e de outras obras do grande artista de Nuremberg.

Como vimos, a consagração da melancolia nos círculos neoplatônicos de Florença e a subseqüente interpretação da obra de Dürer emprestam uma coerência retrospectiva a todo o projeto de Saturno e a melancolia. Diante dessa impressão - e dos assombrosos recursos eruditos demons- 
trados pelos autores - um leitor casual não imaginaria que a própria composição desse livro sofreu tantas idas e vindas, no decorrer das quais muito material foi acrescentado, bastante foi expurgado e certamente algum foi simplesmente perdido.

2

Ao publicar a tradução francesa de Saturno e a melancolia, em 1989, a editora Gallimard tinha toda a razão de apresentá-la ao público leitor como um livro "quase lendário", cuja história "resume a do século XX". ${ }^{8}$ Sua origem remonta a princípios dos anos 1920, quando um conjunto de jovens brilhantes, na maioria judeus, reunia-se diariamente na extraordinária biblioteca do colecionador e historiador da arte Aby Warburg (18661929), em Hamburgo. Warburg estava nessa época internado numa casa de repouso, na Suíça, em tratamento psiquiátrico, depois de alguns anos de intensa luta para continuar trabalhando em meio à sua crescente instabilidade emocional [cf. Saxl: 1944, 303-4]. A biblioteca em sua casa ficara aos cuidados de Fritz Saxl, que em 1921 conseguiu transformá-la num instituto de pesquisas - a Kulturwissenschaftliche Bibliothek Warburg (KBW: "Biblioteca Warburg de Ciências Culturais"). Em 1923, o segundo volume dos Studien der Bibliothek Warburg foi um trabalho conjunto de Saxl e Panofsky intitulado Dürers 'Melencolia I'. Eine quellen- und typengeschichtliche Untersuchung [“'Melencolia I', de Dürer: uma investigação das fontes e tipos históricos”].

Três anos depois, o estudante de filosofia Raymond Klibansky, recémadmitido ao grupo warburguiano, com apenas 21 anos, aventurou-se a criticar a publicação de seus colegas mais velhos. A reação de Panofsky e Saxl foi convidá-lo a participar da reformulação do trabalho, como colaborador [cf. G. Leroux: 1998]. . Começou aí a história de Saturno e a melancolia, exatamente no período em que Panofsky se dedicou de maneira mais assídua à reflexão teórica sobre o ofício de historiador da arte. Cabe lembrar que a primeira elaboração do método iconológico ainda não fora redigida, mas o contato com a sociologia do conhecimento proposta por Mannheim já ocorrera. 
Os três pesquisadores ainda não tinham concluído a segunda edição revista quando se deu a ascensão do nazismo ao poder. Os warburguianos perceberam que a situação não demoraria a se tornar insustentável, sobretudo por sua origem predominantemente judaica. Logo se daria a dispersão do círculo. Warburg morrera em 1929. Já em 1933, um comitê ad hoc de intelectuais e filantropos britânicos convenceu Saxl a transferir a biblioteca para Londres (dando origem ao prestigioso Warburg Institute, hoje pertencente à Universidade de Londres). Também nesse ano Klibansky seguiu o mesmo destino, indo depois lecionar em Oxford, com temporadas cada vez mais freqüentes em Montreal. Panofsky vinha há alguns meses dividindo seu tempo entre a Universidade de Hamburgo e a Universidade de Nova York, para onde partiu com sua família em princípios de 1934 [cf. Hart: 1993, 563 n. 71].

O trabalho foi afinal concluído nesses anos de adaptação a novos cenários culturais e acadêmicos, e apesar das longas temporadas de interrupção, devido à distância entre os autores. Uma editora de Glückstadt, entretanto, aceitou publicar o livro, mas as provas finais só foram retornadas no verão de 1939, semanas antes da eclosão da Segunda Guerra Mundial. Pouco depois do armistício, em 1945, os autores foram informados de que as matrizes de chumbo, já compostas, tinham sido destruídas durante as hostilidades. Por sorte, fora preservada em Londres uma cópia das provas corrigidas; desiludidos com a série de adversidades sofridas pelos originais, certamente chocados com as notícias sobre o genocídio dos judeus nos campos de concentração alemães e já estabelecidos em seus novos países de exílio e idiomas de adoção, os autores decidiram publicar apenas uma tradução em inglês da obra. A morte de Saxl, em 1948, provocou mais adiamentos. Saturn and Melancholy finalmente saiu do prelo em 1964, pela editora londrina Thomas Nelson \& Sons.

Mas a gesta do livro não pára aí. Quando a editora Einaudi decidiu empreender uma tradução italiana, Panofsky já tinha morrido e os clichês das ilustrações da edição original estavam perdidos. Depois de uma demorada reconstituição das mais de 150 reproduções, o volume saiu em 1983. Nessa época Pierre Nora já vinha planejando incluir uma versão francesa na coleção "Bibliothèque des Histoires", por ele dirigida. Aproveitando o 
trabalho dos editores italianos, a Gallimard entregou a tarefa da tradução a Fabienne Durand-Bogaert e ao erudito Louis Évrard. Foi então que o único remanescente dos três autores decidiu fazer novas interferências. Consultado por Évrard sobre os originais das citações de textos antigos, Klibansky passou a participar com muito empenho da nova edição em francês; acrescentou um "Avant-propos", dezenas de notas de rodapé e dois apêndices, participando ainda da seleção de mais material iconográfico, elevando o total de figuras examinadas a 179.

O lançamento da primorosa tradução francesa se deu em 1989. Dois ou três anos depois, a tiragem estava esgotada; é de se supor que a editora não parou de receber pedidos, já que acabou reimprimindo o livro em 1994. Não seria o caso de fazer aqui uma resenha das apropriaçóes de Saturno e a melancolia desde sua publicação atrasada — nem isto estaria ao meu alcance, no momento. É impossível deixar de notar, no entanto, a influência exercida pela reconstrução erudita empreendida por Klibansky, Panofsky e Saxl. Seria razoável supor que o tema da melancolia foi redescoberto após 1964 e depois do aparecimento da versão francesa. Numerosos artigos, teses e livros foram publicados desde então, sob a inspiração direta ou indireta de Saturno e a melancolia, não só na área de História da Arte, mas também na de História da Literatura ${ }^{10}$, embora no mesmo período tenha crescido muito o interesse pela visão da melancolia moderna inteiramente diversa e também muito estimulante na perspectiva trabalhada por Walter Benjamin em $A$ origem do drama barroco alemão. Nem sempre a reapropriação dos esforços dos três autores é feita da maneira mais recomendável; freqüentemente Saturno e a melancolia aparece como simples síntese erudita de textos antigos e medievais, dispensando o contato com as fontes primárias; raramente esse recurso se dá depois de alguma reflexão teóricometodológica que leve em consideração esse aspecto da obra citada.

Essa negligência pode ter alguma relação com o fato de os próprios autores de Saturno e a melancolia terem deixado de lado os problemas teóricos que marcaram as origens de sua longa e entrecortada pesquisa. Em centenas de notas de rodapé, há pouquíssimas considerações de fundo metodológico; às vezes, quando ocorrem, elas demonstram que o quadro epistemológico das reflexões de Panofsky e Saxl permanecera inalterado 
desde seus artigos das décadas de 1920 e 1930 - levando-se em conta o fato de Klibansky ser um filósofo e não um historiador. Por exemplo, ao iniciar-se a análise da "Significação de Melencolia P", no segundo capítulo da parte IV, apresenta-se a "significação fundamental" da gravura de Dürer com uma referência conceitual ao mesmo texto de Mannheim que Panofsky citava em seu texto inaugural de $1932 .{ }^{11}$ Diz a nota de rodapé, depois da indicação bibliográfica: “(...) para os nossos propósitos, pareceu-nos necessário substituir a expressão 'significação representacional' (que Mannheim introduziu entre 'significação expressional' e 'significação documentária') pela de 'significação nocional”' [Klibansky et al.: cit., 541, n. 208]. Enfim, entre tantas "significaçôes", a "fundamental" segundo os autores era aquela que se atinha à "questão vital", a saber:

(...) a atitude fundamental perante a vida que se encontra por trás da gravura de Dürer, com sua genealogia complicada ao infinito, sua fusão dos velhos tipos, sua modificação — digamos francamente: sua inversão — das velhas formas de expressão e seu desenvolvimento de um esquema alegórico [idem, ib. (no corpo do texto)].

Percorrida a genealogia infinitamente complicada de Melencolia I e decifrado o seu "esquema alegórico", os historiadores da arte se encontram bastante equipados para ascender heuristicamente até a "atitude fundamental" de significação "por trás" da gravura. Parece mantido o método iconológico, com suas implicaçóes teóricas — e, diga-se de passagem, numa de suas aplicações mais brilhantes e convincentes. No entanto, onde estão as palavras "iconologia", Weltanschauung e Kunstwollen nesse extenso livro? Apenas em referências bibliográficas.

Não é impossível que essa passagem crucial do texto de 1964 seja idêntica à sua versão primitiva, de 1923, considerando que a primeira apropriação da sociologia do conhecimento de Mannheim por Panofsky se dá no início da década de 1920 e aparece num artigo teórico de 1925, em que reformulava o conceito de Kunstwollen [cf. Hart: 1993, 551]. Evidentemente, não se pode criticar uma grande obra por pertencer a seu tempo - mas, depois de tantos percalços, a que tempo pertence Saturno e a melancolia? Como vimos, houve muitas camadas sucessivas de trabalho, entre as décadas de 1920 e 60; o resultado final — história da arte como obra de arte? 
— não traz marcas aparentes; somos informados sobre as fatalidades de seu destino apenas no "Prefácio" escrito em 1964 por Klibansky e Panofsky, já na ausência de Saxl.

Não tendo um tempo precisamente definível à primeira vista, Saturno e a melancolia tampouco tem um lugar: depois de um período de trabalho conjunto em Hamburgo, os autores se dispersaram, fixando-se em Londres (Saxl), Nova York e, depois, Princeton (Panfosky) e Oxford e Montreal (Klibansky). Saxl se tornou antes de mais nada o infatigável diretor do Instituto Warburg, cuja reputação consolidou nos anos 1940. Panofsky viu-se diante da responsabilidade de praticamente "fundar" a história da arte nos Estados Unidos [cf. Hart: cit., 562-566]. E Klibansky não demorou a se afirmar como um dos mestres mais celebrados das universidades francófonas do Canadá, dedicando-se também à trabalhosa edição do Corpus Platonicum Medii Aevi.

Será mais fácil situar Saturno e a melancolia — ou, talvez, ao contrário, apreender melhor seus variados contornos e a costura de sua "não-situação" - através de um recuo estratégico até o ambiente intelectual que viu nascer os primeiros traços de seu projeto. Mais do que isso, vale a pena acompanhar de modo mais atento as etapas de sua démarche, na medida do possível para os objetivos deste ensaio. Minha principal hipótese norteadora é a seguinte: o resultado final do trabalho de Klibansky, Panofsky e Saxl não explicita com toda a nitidez os seus princípios e objetivos teóricos porque sua origem estava visceralmente ligada a algo que desapareceu no percurso: o papel atribuído à Alemanha perante a civilização européia - um papel emancipador e formador, conforme a pedagogia da Bildung desenvolvida e cultivada por alguns dos pensadores alemães mais decisivos para a história da Europa desde o século XVIII.

\section{3}

Quando Panofsky e Saxl se reuniram no início dos anos 1920 para interpretar a "significação fundamental" de Melencolia I, a obra de Dürer era um tema privilegiado da cultura germânica. Juntamente com Holbein, Albrecht Dürer era o grande artista alemão do Renascimento, um "espírito universal" cujas ligações com a arte e o humanismo italianos permitiam 
que ele fosse visto como legítimo antepassado da paixão de Goethe ou Burckhardt, por exemplo, pela Itália. De uma certa maneira, ele representava um momento inaugural da cultura alemã, na concepção da Bildung, que no século XIX foi sendo paulatinamente encampada pelas elites intelectuais germânicas como um princípio estruturante de nacionalidade [ $c f$. A. Assmann: 1993, 29-35].

Panofsky estava ligado à obra de Dürer antes mesmo de se tornar professor da recém-criada Universidade de Hamburgo, envolvendo-se com o grupo de freqüentadores da biblioteca de Aby Warburg na cidade. Sua primeira publicação importante foi um ensaio sobre as teorias artísticas de Dürer, que veio à luz em 1915, em Berlim, e chamou a atenção para o nome de seu jovem autor. Ao tornar-se mais uma presença assídua no endereço de Warburg, encontrou um meio profundamente marcado pela devoção ao gênio de Nuremberg. O próprio anfitrião do grupo — há muito obcecado pelo Nachleben (a "sobrevida"?) da Antigüidade no Renascimento escrevera bastante sobre Dürer desde o início do século.

Entretanto, os tempos eram de vertiginoso declínio da confiança no futuro redentor da Kultur nos moldes tradicionais alemães. O regime imperial conseguira uma última grande mobilização nacional no início da Primeira Grande Guerra, num amplo consenso belicista que açambarcara até a legenda de esquerda mais organizada, o Partido Social Democrata (SPD). A derrota - depois da morte de centenas de milhares de jovens combatentes - derrubara o Kaiser e dera razão às minorias que ficaram de fora. O regime monarquista se tornara insustentável e as manifestações socialistas convulsionavam o país enquanto os novos dirigentes republicanos negociavam com as nações vencedoras um tratado de paz humilhante para a Alemanha. Diante do risco de esfacelamento do Estado, os dirigentes mais moderados se voltaram para a simbologia de Weimar, a cidade que viu o esplendor de Goethe e Schiller, fundando ali a legitimidade de um novo regime republicano.

No meio artístico e intelectual, cresciam as oportunidades de radicalização e rompimento com os velhos compromissos éticos, estéticos e filosóficos. $\mathrm{O}$ expressionismo se difundia, agora representado também no cinema e no teatro. O dadaísmo, em especial, parecia propor uma tabula rasa 
sobre as ruínas da Europa oitocentista e seus ideais. Movimentos menos iconoclastas, como Bauhaus e o dodecafonismo, tampouco pretendiam fundar suas pesquisas numa chave de continuidade frente aos projetos passados da civilização. Por outro lado, em certos grupos que permaneceram ligados à mitologia nacional germânica, como o influente círculo literário de Stefan George, impôs-se uma postura que fazia pouco caso do racionalismo iluminista e apostava tudo no culto elitista das artes e do "espírito” alemão. Bandeiras irracionalistas também se levantavam na arena política, pretendendo reagir ao desânimo trazido pela derrota com um novo impulso ao nacionalismo, agora inteiramente dirigido para as massas nas cidades de todo o país. Era o caso do Partido Nacional-Alemão, monarquista, em cujas fileiras prosperava o anti-semitismo. Na mesma onda, em 1920, surgia nos meios boêmios o Partido Nacional-Socialista, que em 13 anos levaria Adolf Hitler ao poder.

O seleto grupo de freqüentadores da biblioteca de Warburg em Hamburgo parecia inteiramente infenso a toda essa turbulência política e cultural. Na maioria, eram judeus alemães que sequer cogitavam abandonar a formação assimilacionista vigente em suas famílias há algumas gerações, pelo menos. Não se sentiam minimamente atraídos pelo movimento sionista, como Gershom Scholem, nem pela militância intelectual de esquerda, como Walter Benjamin. Seu patrono era um leal monarquista que passara os anos da guerra prevendo o pior, mas sem se manifestar no espaço público. Para ele, como para grande parte dos judeus alemães de sua geração, a Bildung fora "um vetor de assimilação" [cf. A. Assmann: 1993, 80].

Warburg era o filho mais velho de uma abastada família de banqueiros judeus estabelecida desde o século XVIII em Hamburgo, uma cidade mercantil, sem tradição acadêmica. A saúde frágil e o temperamento instável livraram-no da obrigação de dirigir os negócios do pai. Nas duas últimas décadas do século XIX, tornou-se um autodidata particularmente atraído pelas obras de Nietzsche, Burckhardt e Usener [ $c f$. Ginzburg: 1966, 45 e 49]. Muito cedo, no quadro desses grandes nomes da Kultur alemã, deixou-se fascinar por uma questão: a influência da Antigüidade e das tradições pagãs sobre o Renascimento italiano e a alvorada dos tempos modernos. A falta de vínculos institucionais acadêmicos permitiu que ele des- 
prezasse a progressiva separação das disciplinas humanísticas, abrindo espaço para atacar o seu problema de um modo sempre interdisciplinar, o que teria conseqüências decisivas para o grupo de estudiosos que mais tarde se aglutinaria a seu redor. ${ }^{12}$

Foi assim que, inspirado por Nietzsche, Warburg desenvolveu sua teoria das Pathosformeln ("fórmulas do patético"), representações verbais e/ou visuais transmitidas desde tempos imemoriais, carregadas da experiência social, cultural e religiosa do passado. Nas palavras do autor, eram "testemunhos de estados de espírito transformados em imagens", que legavam a sucessivas gerações "os traços permanentes das comoções mais profundas da existência humana” [apud C. Ginzburg: 1966, 45]. ${ }^{13}$ Era na recuperação e na cuidadosa catalogação dessas formas da memória social que o historiador autodidata pretendia compreender o Nachleben da Antigüidade no Renascimento; mas - como assinala Carlo Ginzburg num ensaio que ultimamente tem servido à redescoberta desse autor - Warburg não buscava "a Antigüidade apolínea dos classicistas, mas uma Antigüidade embebida de "pathos dionisíaco" [idem, ib.]. Daí o interesse específico pela "sobrevida” do paganismo na Itália cristã dos séculos XV e XVI.

Era justamente essa experiência arquetípica das sociedades pagãs que Warburg pretendia encontrar in loco, ao vivo e em movimento, em sua expedição aos territórios indígenas no Arizona e no Novo México, entre 1895 e 1896. Sob a dupla inspiração do método etnológico de Hermann Usener para a História das Religiōes, de um lado, e das narrativas de viagens aventurescas e românticas que lera na primeira juventude, o historiador passou cerca de três meses numa das últimas fronteiras do Ocidente, tomando notas e tirando fotografias com sua Kodak último tipo. Para Warburg, o convívio com os índios Pueblos da América do Norte era um modo de o historiador da arte se converter em testemunha ocular das "origens selvagens" que estariam na primitiva base da cadeia de transmissão das Pathosformeln, aperfeiçoando a sua compreensão do paganismo na Antigüidade greco-romana. Saxl, nos meses seguintes à morte do mestre, em outubro de 1929, relembrou a aventura como "uma viagem aos protótipos" [F. Saxl: 1929-30, 291]; Sigrid Weigel, quase setenta anos depois, preferiu descrevê-la nos termos de "um rito de passagem" [S. Weigel: 1995, 
147]. Com essa experiência, o aventureiro de apenas 29 anos alegava ter compreendido a atividade humana da produção de símbolos como um meio de superar o medo do desconhecido, "o desenvolvimento a partir da proximidade mágico-instintiva para o distanciamento intelectual” [apud S. Weigel, cit., 146].

Dos territórios Hopi do velho oeste, Warburg seguiu para Florença, como quem viaja no tempo, mas não da Antigüidade de volta aos finais do século XIX, e sim rumo ao Renascimento. O objetivo era constatar (mais uma vez, in loco) os sinais da "sobrevida" do paganismo na cultura ocidental. Agora, no entanto, ele dispunha de uma teoria para manejar não somente o processo de transmissão das Pathosformeln, mas também sua própria criação no passado remoto.

Era nos quadros dessa teoria que Warburg entendia a arte de Dürer. $\mathrm{O}$ artista de Nuremberg marcava um ponto de reemergência de "fórmulas do patético" remotas no âmbito de uma reação renascentista às restrições da expressão medieval [A. Warburg: 1905, 165; cf. C. Ginzburg: 1966, 44]. Daí o significado profundo do humanismo italiano para Dürer, como uma reviravolta que reatava os elos de transmissão do patético de fundo eminentemente pagão. É assim que Warburg compreendia e interpretava, enfim, a gravura que tanto ocupou seus hóspedes mais jovens e beneficiários Klibansky, Panofsky e Saxl. O centramento no potencial criador do homem - em outras palavras, sua capacidade de inventar e transmitir símbolos - seria sua única saída para vencer o jugo cosmológico da natureza e dos astros ou, no caso, de Saturno e a melancolia:

O sombrio demônio astrológico que devora seus filhos, cuja cósmica luta contra uma outra divindade astral pesa sobre o destino da criatura submetida à sua influência, é na obra de Dürer humanizado, e assim se converte na encarnação plástica do homem que trabalha e pensa [A. Warburg: 1920, 280].

Mas essa "metamorfose humanizadora" [ $c f$. F. Saxl: 1927-8, 869] não representava para Warburg uma superação definitiva, por parte do "homem que trabalha e pensa”, da rede cosmológica em ação no seu destino. Permaneceriam para sempre ativos os "influxos" de seu mapa astral e os "humores” de sua composição fisiológica — que agora podiam ser entendi- 
dos, em linguagem menos esotérica, como condições sociais e psicológicas inscritas na transmissão das "fórmulas do patético", recebidas num processo eminentemente histórico-cultural. O humanismo italiano, porém, exaltaria a dignidade do homem até situá-lo no centro dessa cosmologia, em posição de servir-se de suas nobres capacidades para apropriar-se do destino e de algum modo "manejar" a fatalidade a seu favor. A medicina de Ficino (Francis Yates preferiria dizer: a sua "magia natural" ${ }^{14}$ ) é um bom exemplo dessa profilaxia.

Menos que uma evolução positiva desde o paganismo primitivo até o racionalismo iluminista, o historiador de Hamburgo buscava compreender a convivência entre essas correntes distintas e até antagônicas da experiência humana. ${ }^{15}$ É neste sentido que ele enfocava a cadeia de "fórmulas do patético": a objetivação cultural da memória social e psíquica através da criação de símbolos transmitidos ao longo de milênios e milênios [ $c f$. J. Assmann: 1995, 129]. O acervo daí resultante era o que ele chamava de Leidschatz des Menschen - o "tesouro do sofrimento dos homens". ${ }^{16}$

Ao escrever as considerações sobre Dürer citadas acima, no entanto, o próprio Warburg lutava para resistir à psicose que já vinha se manifestando desde a infância [ $c f$. F. Saxl: 1944, 303]. A gravura de Dürer é analisada no seu longo ensaio sobre a prática de adivinhação da Antigüidade pagã em textos e imagens do tempo de Lutero [A. Warburg: 1920]. Foi sua última publicação antes de ele internar-se, por quatro anos, no sanatório de Bellevue, em Kreuzlingen (Suíça), onde deu entrada em princípios de 1920. Passara os dois anos anteriores dividido entre os acessos de loucura e o trabalho para terminar o livro; dias depois de entregá-lo ao prelo, sucumbiu [cf. F. Saxl: 1944, 304].

\section{4}

É muito irônico que, nas origens de Saturno e a melancolia, esteja um estudioso tão brilhante e tão atormentado quanto Warburg. Saxl já convivia com ele desde 1911; o interesse por astrologia o aproximara do historiador mais velho. Durante o longo afastamento do dono da casa, entre 1920 e 1924, ficou encarregado de cuidar da sua biblioteca, e não demorou a convertê-la num instituto de pesquisas. Panofsky chegou pouco de- 
pois da internação; mudara-se para Hamburgo a convite da universidade que tinha sido fundada no ano anterior. Para ele, freqüentador assíduo da biblioteca de Warburg, o anfitrião devia ser como que uma presença subjetiva.

O ambiente estava impregnado de sua figura grave e, agora, trágica; a começar pelo letreiro à entrada, em caracteres gregos: MNHMO $\Sigma \mathrm{YNH}$, uma homenagem a Mnemósine, personificação da memória e mãe das nove Musas, cujo nome o historiador atribuíra ao projeto mais ambicioso de sua vida: um atlas iconográfico que catalogasse e reconstruísse a memória visual do Ocidente, em sua cadeia de Pathosformeln. ${ }^{17}$ A própria disposição dos livros nas prateleiras, forrando as paredes até o teto e ocupando todo o espaço disponível, tinha sido singularmente organizada pelo colecionador; o princípio da "boa vizinhança" (como ele o batizou) permitia que o usuário encontrasse ao lado do volume procurado outros que tratassem dos mesmos assuntos a partir de disciplinas diversas, de modo a enriquecer a pesquisa. Para Saxl, que relembra esse ambiente com a reverência de um religioso ao entrar no templo, a biblioteca traduzia "a mais completa manifestação das idéias de Warburg" ${ }^{18}$ A irradiação dessa personalidade ausente ressalta na verdadeira parábola que Saxl conta sobre a primeira visita do filósofo Ernst Cassirer à aristocrática mansão na Hamburgo de 1920:

Como encarregado da bilioteca, mostrei as coisas a Cassirer. Ele foi um visitante agradável que ouvia atentamente enquanto eu explicava a intenção de Warburg de dispor os livros de filosofia ao lado de livros sobre astrologia, magia e folclore, e de interligar as seções de arte com as de literatura, religião e filosofia. O estudo de filosofia era para Warburg inseparável daquilo que se chamava "mente primitiva": não podia ser isolado do estudo das imagens na religião, na literatura e na arte. Essas idéias tinham encontrado expressão na arrumação não-ortodoxa dos livros nas prateleiras. Cassirer logo compreendeu. No entanto, quando se preparava para partir, disse, na maneira clara e bondosa que lhe era característica: "Esta biblioteca é perigosa. Terei de evitá-la completamente ou enfurnar-me aqui durante anos. Os problemas filosóficos envolvidos são semelhantes aos meus, mas o material histórico concreto que Warburg colecionou é esmagador" [apud $\mathrm{P}$. Gay: 1968, 45-6]. 
Como é sabido, Cassirer acabou optando por enfurnar-se, tornandose uma influência decisiva sobre os jovens historiadores da arte ali reunidos na ausência do mestre. Mais do que o chiste do filósofo das formas simbólicas, o modo pelo qual Saxl relata essa visita indica o quanto aquela biblioteca era mitificada por seus freqüentadores. Em todo o seu esplendor e variedade - ao ser transferida para Londres, em 1933, continha 60 mil volumes e 25 mil estampas - ela era percorrida e utilizada como se fosse a objetivação material de uma personalidade fortíssima, tão forte que não suportava a si própria.

Foi durante o período de internação de Warburg que Panofsky e Saxl iniciaram as pesquisas que levariam tantas décadas depois à publicação de Saturno e a melancolia. Tudo indica que, àquela altura, o anfitrião ausente era para eles um modelo vivo da turbulência marcante dos engenhos superiores, oscilantes entre a depressão mais sombria e a exaltação sublime do entendimento. Suas lembranças pessoais mostram bem o modo pelo qual eles associavam a figura de Warburg ao temperamento melancólico descrito pela antiga tradição da medicina humoral e da astrologia árabe. Espontaneamente, sem que o desejassem ou mesmo percebessem, falavam dele como uma vítima do mal que começaram a estudar por volta de 1921. É o que vemos nessa recordação de Panofsky, escrita em 1930 para um volume de homenagens ao historiador recém-falecido:

(...) havia nele uma enorme tensão entre o racional e o irracional; (...) não [era] uma cisão romântica, mas uma combinação fascinante de uma inteligência extraordinária e uma melancolia profunda, a mais aguda crítica racional e a mais enfática disposição para ajudar [apud P. Gay, ib., 44].

A ambivalência característica do velho homo literatus - o racional e o irracional, a inteligência e a "melancolia profunda" — é a primeira idéia que ocorre a Panofsky, ao evocar a figura de Warburg, com quem convivera apenas durante os cinco anos entre o restabelecimento (1923-4) e a morte do historiador (1929). As memórias de Saxl, no entanto, são ainda mais esclarecedoras a respeito da impressão que os dois pesquisadores tinham sobre seu anfitrião e amigo, sobretudo considerando-se que Saxl acabaria dedicando 37 de seus 58 anos de vida à marca "Warburg", antes e depois 
da morte dele, e antes e depois da ascensão do nazismo e da mudança para a Inglaterra. O mais interessante é que em Saxl não aparece a palavra "melancolia”, explicitamente, como no depoimento de Panofsky - o que reforça a idéia de que a associação de Warburg ao mito do gênio turbulento era irrefletida e espontânea. Ao contrário, em suas reminiscências, Saxl parece preservar cuidadosamente o seu homenageado, cuidando para que sua história pessoal não comprometesse sua imagem de pesquisador com a pecha de irracionalista.

De todo modo, é notável a devoção de Saxl à memória de Warburg, apesar do relacionamento difícil entre ambos nos últimos tempos de sua amizade e colaboração [cf. C. Ginzburg: 1966, n. 57]. Na conferência "Três florentinos", Saxl traça um comovente retrato do amigo; sem intenção (pelo menos aparentemente), ele parece descrever o próprio "tipo" melancólico segundo a doutrina hipocrática dos quatro temperamentos. Por exemplo, na seguinte passagem:

Desde a infância a vida de Warburg foi assediada por perigos, reais ou imaginários. Tinha uma compleição frágil e sua condição física nunca suportou a tensão exercida pela força que o movia. Nele, sempre esteve vívido o medo do sofrimento [F. Saxl: 1944, 303].

Os excessos imaginativos da melancolia são um traço permanente nas diversas concepções expostas por Klibansky, Panofsky e Saxl em Saturno e a melancolia, culminando com a melancholia imaginativa descrita por Agrippa de Nettesheim, que teria inspirado a famosa gravura de Dürer. Também a propensão ao medo aparece com muita freqüência - era causada, segundo Ficino, pelo "resfriamento" da bile negra. No entanto, o que mais chama a atenção na frase de Saxl sobre Warburg é a "força que movia" o homenageado, exercendo sobre sua "compleição" uma "tensão" insuportável — uma linguagem bastante "ficiniana":

Entre os letrados - escreveu o neoplatônico florentino - são particularmente oprimidos pela bile negra aqueles que se aplicam com zelo ao estudo da filosofia, desprendendo o pensamento do corpo e das coisas corpóreas, para uni-lo às incorpóreas: pois, de um lado, a grande dificuldade de sua empreitada exige uma tensão mental (mentis intentione) forte demais, e, de 
outro, a mente se destaca do corpo de tal maneira a unir-se às coisas incorpóreas [apud Klibansky et al.: 1964, 413, n. 54].

Os males da melancolia, portanto, podem se agravar devido a uma aplicação mental extraordinária, como a exigida pelo zelo nos estudos mais difíceis; tensão, aí, é a palavra-chave. Para Ficino, aliás, todo estudioso estava condenado à melancolia e sujeito a Saturno, "se não pelo horóscopo, ao menos por sua atividade" [idem, 415]. E a oscilação entre os extremos era seu principal tormento, com "a tensão incessante entre o abatimento e a exaltação" [idem, 377]; coincidentemente, Saxl assim descreve a posição de seu homenageado: "Tampouco reconhecia um termo médio para si mesmo"; afinal, ele era "um desses homens cujas vidas se dedicam a um serviço mais elevado" [F. Saxl: 1944, 303].

Evidentemente, não estou tentando demonstrar que Saxl teria "diagnosticado" o mal de Warburg; ao contrário, meu interesse é ressaltar a impressão que o historiador deixara entre seus hóspedes mais jovens, que ironicamente dedicariam décadas de estudo ao tema da melancolia como um componente do conceito de "gênio" na modernidade. Assim, no depoimento de Saxl, nota-se a preocupação do autor em descrever os esforços de Warburg para deter o seu mal; por exemplo, ao eclodir a Primeira Guerra:

Quando estourou o conflito de 1914, sua mente caiu num estado de caos. (...) Como ele podia concentrar-se nos livros em meio a tamanho desespero? Começou então a organizar uma nova seção da biblioteca, dedicada aos problemas culturais da guerra, e compilou um índice em fichas de referência a artigos relevantes de uma série de jornais [idem, ib.].

Essa resistência através da ocupação intelectual só durou até pouco depois do armistício. Mas foi suficiente para que ele terminasse um último grande empenho:

Quando chegou a catástrofe da Alemanha, Warburg afundou. Mas até inícios de 1920 lutou para acabar seu livro sobre as profecias pagãs no tempo de Lutero. Dias depois de ele ficar pronto para o prelo, internou-se numa clínica de repouso (...) [idem, 304].

Era como se o mal psíquico do historiador correspondesse, num plano macrológico, ao desmoronamento político e cultural da Alemanha. 
Ambos, micro e macro, pareciam submergir sob o signo de uma fatalidade comum.

De todo modo, segundo Saxl, Warburg não deixaria de trabalhar na infatigável reflexão sobre as questões que há tanto eram para ele uma obsessão estudiosa:

Durante quatro anos enfrentou aqueles demônios, cujo impacto nas crenças do Renascimento estudara como erudito. Sua mente estava presa a uma rede tecida de medos aborígines e memórias adquiridas. Entretanto, ele forçou o retorno à claridade de um modo memorável, pronunciando no hospital, para um público de pacientes, uma conferência sobre a serpente na religião e na arte, baseada em sua antiga experiência com os índios americanos, que ele então relacionaria com o Laocoonte e com as figuras cristãs da serpente de bronze. Tanto a enfermidade quanto a saúde chegaram a Warburg através do estudo da tradição pagã [idem, ib.].

Pelo estudo, Warburg se tornara louco; através do estudo, voltara a si. A passagem é narrada por Saxl como a luta interior de um homem em busca de um retorno ao esclarecimento. Refere-se à conferência sobre o "ritual da serpente", cerimônia que o historiador testemunhara entre os índios do Novo México, 27 anos antes, e agora expunha a seus companheiros de infortúnio no sanatório de Bellevue.

O conteúdo principal, no entanto, era a teoria das Pathosformeln como criação humana de símbolos para superar o medo e as experiências de sofrimento. Assim, por exemplo, ele explicava a associação que os Pueblos faziam entre a serpente e o aterrorizante raio: "A serpente é (...) um símbolo universal entendido como resposta à seguinte pergunta: de onde vêm a fúria dos elementos, a morte e a dor? (...) Talvez se possa dizer que, onde a dor humana, atônita, procura sua redenção, estamos na proximidade da serpente como causa explicativa imaginária” [A. Warburg: 1923, 62].

Para o psiquiatra que dirigia o hospital em Kreuzlingen, o esforço de seu erudito paciente era notável, mas não deixava de ser composto como "um entrelaçamento de suas opiniōes acadêmicas e seus delírios" [apud S. Weigel: 1995, 149]. O próprio convalescente, em carta a Saxl, proibia-o de divulgar o texto de sua conferência, agradecendo-lhe "por ter assistido o parto desta monstruosidade, como valente parteira" [A. Warburg: 1923a, 
68]. Contudo, o dedicado secretário via no mesmo trabalho o engenho criativo do amigo em plena retomada de seu movimento. Analogamente, a Alemanha também tentava mover-se e reagir à sua crise. Em ambos os casos, era como se se tratasse de uma querela alemã por excelência. Assim como "Lichtenberger, Dürer e Lutero representaram três fases do alemão em luta contra o fatalismo cosmológico e pagão" [A. Warburg: 1920, 281], o próprio Warburg estava fadado a representar mais uma.

A devoção dos jovens "warburguianos" a seu anfitrião, porém, não se estendia a suas idéias. A geração de Panofsky e Saxl tinha perante Warburg uma atitude de reverência pessoal, mas não sem reservas no terreno intelectual. As transformações políticas recentes pareciam aprofundar essas divergências ainda mais. No princípio dos anos 1920, o desatino de Warburg coincidia com o desatino da República de Weimar, na primeira das duas grandes ondas hiperinflacionárias que marcariam o período. Desde o dia da internação do historiador até sua alta, em 1924, o índice de desemprego subira de $6 \%$ para $27 \%$ da população ativa da Alemanha (ou 1,5 milhão de desempregados). A cotação do marco frente ao dólar caíra de 9 mil por 1 para 1 bilhão por 1, enquanto os preços dos gêneros de primeira necessidade subiam várias vezes por dia. A famosa biblioteca de Hamburgo deve ter vivido um período de estagnação quanto ao ingresso de novos títulos, pois a aquisição de livros tornara-se um luxo inacessível. Em ambientes da alta burguesia como a mansão Warburg, os menores confortos do cotidiano se tornavam cada vez mais exorbitantes — quando não desapareciam do mercado, como a água mineral e até o açúcar [ $c f$. L. Richard: 1983, 94-6]. Panofsky, um fumante inveterado, via o preço de um maço de cigarros atingir a cifra astronômica de 4 bilhões de marcos! ${ }^{19}$

Esse ambiente de desespero econômico provocou um período de pânico social sem precedentes na Alemanha moderna. Entretanto, Panofsky e Saxl permaneciam impassíveis. Enquanto compulsavam edições raras da obra de Marsílio Ficino e catalogavam representaçôes alegóricas da melancolia em folhetos da Idade Média, na "vida real" os mais pobres saqueavam as padarias e os mais ricos cercavam-se com grades mais altas, com medo de assaltos. O sentimento geral de desagregação favoreceu o recrudescimento do anti-semitismo, culminando com o assassinato do ministro das Rela- 
ções Exteriores, Walter Rathenau, de origem judaica. $\mathrm{O}$ afã assimilacionista perigava desmoronar, à medida que o próprio ideal alemão de civilização era posto em dúvida com a emergência de forças obscuras que ele próprio engendrara. Não me parece irrelevante que a primeira versão de Saturno e a melancolia seja balizada pela fundação do Partido Nacional-Socialista (1920, ano dos primeiros contatos entre Saxl e Panofsky) e o Putsch de Hitler em Munique (1923, ano da publicação de Dürers 'Melencolia I).

Naquele momento em que prosperava o aberto apelo ao irracionalismo e ao nacionalismo mais chauvinista, insistir na ênfase de Warburg no "lado dionisíaco" da Antigüidade pagã soaria, aos ouvidos de Panofsky e Saxl, no mínimo como algo de mau gosto. Evidentemente, as idéias warburguianas nada tinham de irracionalistas [cf. C. Ginzburg: 1966, 46], mas a própria rivalidade entre os jovens historiadores da arte e o grupo de satélites de Stefan George pressionava no sentido de uma adesão mais clara à razão. Warburg tinha desenvolvido sua teoria dos símbolos num contexto inteiramente outro; agora, a filosofia de Nietzsche era reclamada pelos defensores do super-homem eugênico, enquanto o método etnológico de Usener servia às bandeiras nacionalistas. ${ }^{20}$

Assim como empurrou muitos para o chauvinismo e o irracionalismo, o desespero da Alemanha nesses anos renovou, para Panofsky e Saxl, o seu pertencimento à tradição da Bildung universalista, contra a versão exclusivamente germanista desse ideal, nos termos postos por Aleida Assmann [1993, 80]. Não que Panofsky e Saxl passassem, naquele momento, por uma crise e uma transformação tão profundas quanto as que Thomas Mann enfrentara, abandonando radicalmente sua profissão de fé apolítica e rompendo com o elitismo da Kultur e sua tradição [ $c f$. W. H. Bruford: 1975, 226-263]. Ao contrário, sua reação era de retomada da confiança no ideal individualista de cultivo de si, afastando porém as correntes mais "sombrias" dessa tradição; a melancolia dos engenhos superiores é para eles uma afecção ascética: uma "exacerbação da consciência de si", que permite o acesso individual às mais altas esferas do entendimento [cf. Klibansky et al.: 1964, 371-387].

É assim que Panofsky e Saxl deixam de lado as idéias de Warburg, ao mesmo tempo em que iniciam uma interlocução muito prolífica com Ernst Cassirer, que então desenvolvia sua "filosofia das formas simbólicas" sobre 
uma base kantiana. Era um engajamento "estudioso", a portas fechadas, "enfurnado" na Warburg Bibliothek - enquanto Thomas Mann apelava a um engajamento ativo nas ruas, em defesa da democracia. Da perspectiva do escritor, a posição dos "warburguianos" era, sim, uma decisão política, mas "em favor da causa errada". ${ }^{21}$

Nesse contexto, o renovado interesse pela obra de Dürer se revestia de uma significação política que desapareceu na versão final de Saturno e a melancolia - até porque esse empenho fracassou depois de 1933; a partir de então, a Kultur alemã teria cada vez menos a dizer para dois imigrantes judeus no mundo positivista das universidades britânicas e americanas. Todavia, na Hamburgo de princípios dos anos 1920, a pesquisa sobre a Bildung de Dürer era uma discreta manifestação de confiança em meio ao caos, mas também de indiferença política, por outro lado. Saxl, nesses anos, vinha se empenhando em pesquisas que afastassem de seu velho interesse pela astrologia o elemento dionisíaco que tanto importava para Warburg [cf. Ginzburg: 1966, 53-4] e que ameaçava irromper nas manifestaçóes populares de esquerda e de direita por toda a Alemanha desde a derrota de 1918. Agora, a Antigüidade cuja "sobrevida" ele e Panofsky buscavam detectar no Renascimento não era mais a especificamente "pagã", mas sobretudo a "clássica". Em seu artigo sobre a mitologia antiga na Idade Média, publicado nos Estados Unidos em 1933 (!), eles frisavam que a retomada de formas clássicas no Renascimento não indicava uma permanência e sim a consciência de uma distância, com "a descoberta do sistema histórico moderno" [apud Ginzburg: cit., 50]. É justamente o oposto do que Warburg pensava.

\section{5}

A visada sobre o surgimento da consciência histórica — uma questão cara à filosofia de Cassirer - já aparece preliminarmente esboçada no ensaio de Panofsky sobre Dürer publicado em 1921: "Dürer e a Antigüidade clássica” [Panofsky: 1920-1]. Contudo, ao longo da vasta argumentação, a gravura Melencolia I não é citada; ao que parece, ela estava reservada para o trabalho conjunto com Saxl. Para eles, já não seria possível manter a interpretação de Warburg, citada acima. A “encarnação plástica do homem que 
trabalha e pensa” não poderia ser vista como o resultado da convivência de um pagananismo transmitido de geração em geração com uma "metamorfose humanizadora" que manejasse a magia pagã a favor do homem ascético, conduzindo à vitória final de Júpiter sobre Saturno.

Tratava-se muito mais, para Panofsky e Saxl, da retomada de uma tradição filosófica antiga (o "furor divino" associado ao "Problema XXX, 1") a serviço da nova condição humanista, dividida entre a exaltação da razão, com seu "poder quase divino", e o abatimento do corpo, na "consciência de seus limites naturais" [Klibansky et al.: 1964, 394]. Apenas num ponto eles concordariam com Warburg: Melencolia I traduz um ato de insubmissão humanista ao determinismo cosmológico.

Saxl, num texto bem mais próximo da versão primitiva de Saturno e a melancolia, assim se refere à gravura de Dürer: "Sua Melancolia é um símbolo da mente individual que busca sua imagem no espelho do universo" [F. Saxl: 1927-8, 69]. Logo em seguida, ele cita a interpretação de Warburg sem apresentar qualquer discordância, mas fora do contexto da teoria das Pathosformeln e da "sobrevida" da Antigüidade pagã. Era um modo de conservar a reverência ao mestre - que ainda estava vivo — sem abrir espaço à divergência teórica (ou melhor: filosófica). ${ }^{22}$ Em Saturno e a melancolia, a posição warburguiana é citada apenas numa nota de rodapé:

Não é sem alguma reserva que nos associamos a suas observações [de Warburg], porque não podemos imaginar que a luta demoníaca entre Saturno e Júpiter se encerre com a vitória do segundo [Klibansky et al.: 1964, 505, n. 148].

No mesmo trecho, além disso, os autores relativizam a importância dada por Warburg ao quadrado mágico (mensula Jovis, um talismã para atrair a influência de Júpiter), como "apenas mais um motivo entre tantos outros, e de modo algum o mais importante”. Ao contrário, toda a ênfase da interpretação de Panofsky e Saxl é dirigida à conexão perfeitamente racional entre o "tipo melancólico" e o "tipo geométrico" na composição de uma única figura alegórica [idem, 493-583].

Comparada à perspectiva de Warburg, a de Panofsky e Saxl desvaloriza a magia hermética e sobrevaloriza a geometria e seus instrumentos de domínio sobre o mundo e a contingência. O elogio iconológico a Dürer 
era também um chamado à razão. Mas não a uma razão que emanasse do espaço público para os espíritos privados e sim o contrário: o exercício individual da razão era a única saída diante dos impasses da condição mortal do homem e do fardo cosmológico sobre seu destino. Essa apologia vai ainda além quando Panofsky, em texto de 1931, debruça-se sobre a série dos "Quatro apóstolos" de Dürer, pintada na década de 1520, depois da conversão do artista ao protestantismo. Nesse artigo, o autor apresentava em linhas gerais a reflexão que em 1964 apareceria incorporada a Saturno e a melancolia [idem, 574-583]. Se Melencolia I representava, conforme o esquema de Agrippa de Nettesheim, o degrau mais baixo das propensões dirigidas pela bile negra, a melancholia imaginativa dos grandes artistas, o retrato de S. Paulo ascendia ao degrau superior, a melancholia mentalis dos grandes teólogos.

São três níveis de melancolia em muito análogos aos três níveis de ação iconológica do historiador da arte sobre seus objetos, num movimento semelhante de ascese ao transcendente. É verdade que o método tripartite de Panofsky foi desenvolvido sob a inspiração de Mannheim, como Joan Hart demonstrou, mas é irresistível, para os propósitos deste trabalho, comparar as tabelas expostas pelo iconologista em 1939 e 1955, expondo sua metodologia, com a outra incluída em Saturno e a melancolia para explicar o sistema de Agrippa. ${ }^{23}$

Sem pretender que o sistema exposto por Agrippa em De occulta philosophia tenha tido qualquer influência no desenvolvimento da iconologia, parece-me lícito utilizá-lo como ilustração primitiva da legitimidade há muito estabelecida na cultura européia para uma empresa de "elevação" do entendimento aplicado à "profecia"/cognição de "eventos"/ significados transcendentes. Como na tabela mannheimiana que distingue em três níveis a apreensão do sentido de uma obra de arte - pela ordem: pré-iconográfico, iconográfico e iconológico - esta antepassada do século XVI reserva a operação "superior" para o último degrau, onde um determinado tipo de melancolia, diante da ação do melancólico sobre si mesmo, dá acesso à compreensão de grandes eventos na esfera da espiritualidade (à qual a Alemanha do futuro atribuiria o estudo das $\mathrm{Hu}$ manidades: Geisteswissenschaften). 
Apesar dessa proximidade analógica, Klibansky, Panofsky e Saxl restringiram sua abordagem da obra de Agrippa ao essencial para a interpretação da gravura Melencolia I, sobretudo quanto à explicação do algarismo " $P$ " no título; ficou de lado o caráter eminentemente mágico da doutrina desse pensador, que ensinava a atrair os influxos dos planetas conforme efeitos desejados em cada caso [cf. F. A. Yates: 1964, 130-143].

Panofsky e Saxl só se aprofundaram na correlação entre Agrippa e Dürer a partir do contato com Klibansky. Mesmo assim, a desvalorização da magia de fundo pagão em favor dos aspectos racionais e formadores do Ocidente já era um movimento praticado pelos historiadores da arte quando escreveram Dürers 'Melencolia I', no início da década de 1920. O exercício iconológico (avant la lettre) de Panofsky e Saxl já vinha purgando a tradição "warburguiana" de seu apego inicial às correntes que naquele momento pareciam desatinar, tanto na trajetória pessoal do historiador quanto na situação política da Alemanha. Ao mesmo tempo, Panofsky ia enfrentando os problemas teóricos que se levantavam para a História da Arte no contexto germânico, num esforço de reflexão que culminou com o texto de 1932, já contendo o essencial da iconologia enquanto método de interpretação. No lugar das "fórmulas do patético", entravam as "formas simbólicas": sai Nietzsche e entra Kant.

Naquele momento, tais providências demarcavam uma posição firme diante do ideal germânico do cultivo pessoal, consciente ou não por parte de Panofsky e Saxl. Sua adesão a esse ideal, evidentemente, não era uma paranóia nacionalista, de fundo racial, mas simplesmente um patriotismo legítimo para qualquer judeu alemão do período, de fundo cultural. ${ }^{24}$ Todavia, não era um elogio restritivo à Alemanha o que os iconólogos teciam, ao se debruçarem sobre a grandeza do alemão Dürer. Ao contrário, o reforço da identidade alemã desse artista e de seus intérpretes servia ao engrandecimento da Europa, que o humanismo italiano transformara na pátria maior do Homem. A Bildung, originalmente, era entendida como a melhor contribuição alemã para essa entidade político-cultural.

A partir de 1933, os acontecimentos se precipitaram de tal modo que o elogio da Europa a partir da Alemanha se tornara subitamente impensável. 
Ao contrário, dentro de poucos anos, era a Alemanha que ameaçava levar todo o ideal civilizatório europeu à ruína. $\mathrm{O}$ esforço erudito de reformulação do trabalho publicado em 1923 perdera o sentido. A partir de 1939, particularmente, o projeto que levaria à publicação de Saturno e a melancolia em 1964 perderia de uma hora para outra os referenciais históricos e culturais de sua primeira elaboração, resultando num livro de impressionante erudição e comovente devoção ao humanismo, mas esquivo acerca de suas origens, métodos e pressupostos.

Um episódio da biografia de Klibansky ilustra bem o quanto os autores de Saturno e a melancolia estavam engajados no ideal europeu de redenção da humanidade pelo esclarecimento e a educação. Tendo imigrado para a Inglaterra em 1933, ele foi convocado para servir às Forças Armadas da Grã-Bretanha, com a patente de coronel. Aos 34 anos de idade, o coronel Klibansky se viu engajado no serviço de inteligência do Exército britânico, tentando fazer os generais aliados compreenderem que a Campanha da Sicília seria um fracasso: desde Aníbal até Garibaldi só era possível conquistar a Península Itálica pelo Norte ou pelos flancos. Uma vez ao menos ele conseguiu convencê-los a seguir seus conselhos: foi assim que evitou um bombardeio da Royal Air Force a Cusa; talvez ele não tenha confessado aos generais que o cardeal Nicolau de Cusa era sua principal obsessão filosófica desde que editara as obras completas desse filósofo, em 1927, pela Universidade de Heidelberg.

Em 1953, há quase 20 anos lecionando nos Estados Unidos e amplamente festejado na Universidade de Princeton, Panofsky ainda se considerava "um europeu transplantado", apresentando-se ao público americano como um "imigrante humanista" [Panofsky: 1953, 438], como se ele (tendo perdido a "pátria" de sua certidão de nascimento) viesse de um país estranho à América e consubstancial à Europa, o "humanismo". ${ }^{25}$ Mas tudo isso com muito bom humor. Na tranqüilidade de sua "arcádia" acadêmica, debaixo da proteção institucional e afetiva que as agências filantrópicas americanas dispensam aos grandes mestres universitários, ele parecia querer inventar uma suave Bildung americana, recomendando os estudos humanísticos às escolas secundárias e protestando veladamente contra a 
“caça às bruxas"; nos Estados Unidos dos anos 1950, ele temia a reaparição dos fantasmas do nacionalismo e da intolerância, "as mesmas forças que nos expulsaram da Europa em 1933" [idem, ib.]. Et in Arcadia ego, teria pensado o grande historiador.

Adaptado na medida do possível a um país onde, ao contrário da Alemanha de seu tempo, as ciências biomédicas e tecnológicas garantiam muito mais prestígio do que as humanidades, Panofsky via seus filhos seguirem carreira na Engenharia e na Biologia, ao mesmo tempo em que fazia conferências em linguagem simples para multidões de estudantes fascinados por seu carisma. Alguma melancolia deve ter se aquecido em seu próprio temperamento, depois de tantos anos de aturadas pesquisas. Mas ele aprendera a lição do comedimento; entre os atrabiliários, preferia os ascetas da melancholia mentalis. ${ }^{26}$

Daí o elogio do "S. Paulo" pintado por Dürer. Mas, pela classificação de Agrippa, também S. Jerônimo mereceria do artista o mesmo tratamento. E mereceu, até certo ponto, em pelo menos uma das muitas obras que ele dedicou ao tema. A gravura "S. Jerônimo em seu estúdio" (de 1514, como Melencolia I) representa esse doutor da Igreja concentrado no trabalho (fig. I). Assim Panofsky se refere a ela, num livro já escrito nos Estados Unidos, voltado para "o público em geral":

É um estúdio bastante simples, embora muito aprazível, provido não só das necessidades mas também dos pequenos confortos de uma vida devota e estudiosa. (...) Essa atmosfera só pode ser descrita com duas palavras alemãs intraduzíveis: gemütlich e stimmungsvoll. Termos em inglês como snug ("acolhedor") ou cozy ("aconchegante") podem exprimir o sentimento de intimidade, calor e proteção que perpassa o sacrário de $S$. Jerônimo, banhado como está por uma suave claridade do sol, sob a qual até o crânio em cima do peitoril da janela parece mais amigável do que aterrorizante. Mas eles não chegam a sugerir adequadamente o que pode ser chamado de clima espiritual. A entrada do estúdio está bloqueada pelo leão de S. Jerônimo, que cochila no contentamento de seu tédio, mas mantém um olho semicerrado, suspeitoso de possíveis intromissões do mundo exterior. Um cãozinho dorme pesado, encostando suavemente a patinha no pé do leão. O próprio Santo está trabalhando no fundo do cômodo, que por si só dá a impressão de isolamento e paz. Seu pequeno atril está sobre uma mesa ampla onde não há nada mais além de um tinteiro e um crucifixo. Concentrado na escrita, 
Jerônimo está prazerosamente sozinho com seus pensamentos, seus animais, seu Deus [E. Panofsky: 1943, 154-5].

É um cenário fascinante para um estudioso como Panofsky. Ainda mais encantador para ele - e para nós também! — é poder "espiar" esse momento de introspecção de um homem santo:

O espectador se sente bem perto do limiar do estúdio, recostado num dos degraus que levam até ele. Mesmo despercebidos pelo santo tão ocupado, e sem invadir sua privacidade, podemos compartilhar com ele o espaço de sua habitação, como se fôssemos amigáveis visitantes não vistos, ao invés de remotos observadores [idem, 155].

Uma sensação parecida de violação da privacidade alheia é a que sentimos diante de uma fotografia mostrando Panofsky em seu escritório de Hamburgo, nos anos 1920 [fig. II]. Flagrado junto à estante, folheando um pequeno volume, possivelmente aberto para uma consulta rápida, já que ele está de pé e tem um lápis na mão, Panofsky aparece contra a quina de sua confusa biblioteca particular, onde os livros estão enfileirados sem muita ordem, certamente porque a todo momento são requisitados e levados para fora de seu lugar. Essa desordem, porém, não é a única diferença entre a fotografia e a gravura; aqui, o estudioso percebeu que está sendo observado; o clic parece marcar o exato momento em que ele se vira para a câmera. Fomos descobertos! E as sobrancelhas franzidas de Panofsky demonstram que ele não gostou nada de ser espionado.

A suave melancolia descrita por Panofsky a propósito do "S. Jerônimo em seu estúdio" é um ideal estranho a Saturno e a melancolia. O prazeroso isolamento do estudioso "com seus pensamentos, seus animais, seu Deus" nada tem a ver com o ideal humanista que apontava para a contínua superação dos limites impostos pela natureza ao entendimento humano. A diferença entre o "S. Paulo" e Melencolia I é de grau, segundo a escala de Agrippa; mas o que distingue o "S. Jerônimo" de Melencolia I não é o temperamento nem o grau, e sim o próprio espírito: na linguagem de Klibansky, Panofsky e Saxl, é a diferença entre o erudito medieval que pretendia "unirse a Deus" e o gênio humanista que aspirava a "competir com Deus" [Klibansky et al:: 1964, 392]. 
Nos tempos em que o projeto de Saturno e a melancolia foi delineado, Panofsky ainda não tinha descoberto o ideal de "S. Jerônimo", tão preso que ele e seus colegas de geração estavam às altas aspiraçóes do humanismo europeu e a seu conflito entre o "lado dionisíaco" e o exemplo clássico. Nos Estados Unidos, essas questões tornaram-se tão distantes quanto o próprio Velho Continente. O historiador parece ter descoberto então os prazeres de "servir a Deus", ele próprio - mesmo que ao Deus laico das pequenas causas do cotidiano. As muitas ironias que o século XX infligira a seu destino pessoal e a confortável situação de que ele desfrutava como "europeu transplantado" fizeram-no descobrir um ideal diferente daquele representado em Melencolia I e mais próximo do retiro modesto de $\mathrm{S}$. Jerônimo. Mais próximo, também, daquela "gravidade sem peso" de que falava Italo Calvino.

\section{Notas}

${ }^{1}$ Registre-se que Calvino começou a preparar suas Lezione americane em 1984, um ano depois da publicação da tradução italiana da obra de Klibansky, Panofsky e Saxl [Saturno e la melanconia. Studi di storia della filosofia naturale, religione e arte. Turim: Einaudi, 1983].

${ }^{2}$ Sobre a influência de Cassirer, ver E. Neiva: 1993, 20-24; quanto à apropriação muito particular que Panofsky faz da metodologia sociológica de Mannheim, J. Hart: 1993; o esquema tripartite de Mannheim está exposto no artigo "Sobre a interpretação da Weltanschauung", de 1922, citado por Hart.

${ }^{3}$ Acerca das conseqüências dessa terminologia, remeto para as interessantes consideraçôes de H. U. Gumbrecht [1994, 391].

${ }^{4}$ Enquadravam-se nesse tipo as críticas de Th. Frangenberg a Arquitetura gótica e escolástica [Panofsky: 1951]; cf. Frangenberg: 1979.

${ }^{5}$ Cf. Ginzburg: 1966, 74-5; alguns pontos centrais da crítica de Gombrich encontram-se em Meditations on a Hobby Horse [Gombrich: 1963] e Symbolic Images [Gombrich: 1972].

${ }^{6}$ Compare-se, por exemplo, as duas versões americanas do texto hoje clássico sobre a iconologia [1939 e 1955] com a primeira exposição do método [1932], bem menos didática.

${ }^{7}$ Note-se que o texto de 1932, em certa medida, é uma reação às críticas de Heidegger às práticas de interpretação derivadas da filosofia kantiana [cf. Panofsky: 1932, 248-255].

${ }^{8}$ Refiro-me ao texto de apresentação impresso na contracapa da jaqueta protetora da edição francesa.

${ }^{9}$ Cito aqui o prefácio de Georges Leroux a seu livro de entrevistas com Klibansky; infelizente, não tive o livro em mãos e só pude consultar a transcrição integral do prefácio, 
no site da livraria Gallimard/Montreal, na internet; o endereço eletrônico consta da bibliografia.

${ }^{10}$ Limito-me a citar os títulos que conheço melhor, nas áreas de História da Literatura e História das Idéias, pela ordem de publicação: B. G. Lyons [1975]. Voices of Melancholy. Studies in Literary Treatment of Melancholy in Renaissance England. Nova York: Norton; M. A. Screech [1983]. Montaigne \& Melancholy. The Wisdom of the 'Essays'. Londres: G. Duckworth \& Co.; K. H. Dolan [1990]. Cyclopen Song: Melancholy and Aestheticism in Góngora's 'Fábula de Polifemo y Galatea'. Chapel Hill: North Carolina Studies in the Romance Languages and Literatures; T. S. Soufas [1990]. Melancholy and the Secular Mind in Spanish Golden Age Literature. Columbia MI: University of Missouri Press; H. Ferguson [1995]. Melancholy and the Critique of Modernity. Søren Kierkegaard's Religious Psychology. Londres: Routledge.

${ }^{11}$ Trata-se de "Beiträge zur Theorie der Weltanschauungsinterpretation" ["Contribuições à teoria da interpretação da Weltanschauung"], originalmente publicado no Jahrbuch für Kunsgeschichte de 1921-2.

${ }^{12}$ Sobre a perspectiva interdisciplinar de Warburg, ver M. Diers: 1995, 60; e S. Weigel: 1995, 139-40.

${ }^{13}$ Ainda quanto ao conceito de Pathosformeln, ver S. Weigel: cit., 137-9.

${ }^{14}$ Ver F. A. Yates: 1964, 62-83; registre-se a coincidência de este livro ter sido publicado no mesmo ano que Saturno e a melancolia, e sob os auspícios do Warburg Institute; uma das fontes secundárias de Yates é a obra primitiva de Panofsky e Saxl sobre Melencolia I. ${ }^{15}$ Estou discordando, neste ponto, da perspectiva de $S$. Weigel em seu belo artigo analítico acerca das memórias de Wargurb sobre sua expedição [S. Weigel: 1995, 147].

${ }^{16}$ M. Diers [1995, 68] cita uma frase a esse respeito, retirada das anotações particulares de Warburg, com data de 1928: "O tesouro do sofrimento dos homens passa a pertencer à humanidade".

${ }^{17}$ Sobre esse projeto inacabado, ver J. Assmann: 1995, 128-9; e M. Diers: 1995: 70-73.. ${ }^{18}$ Opiniāo de F. Saxl citada por Gertrud Bing, sua colega desde Hamburgo e sucessora na direção do Warburg Institute, a partir de sua morte, em 1949; apud C. Ginzburg: 1966, n. 3 .

${ }^{19}$ W. S. Heckscher $[1993,180]$ conta que a primeira onda de hiperinflação foi suficiente para arruinar a fortuna da família de Panofsky, que parecia solidamente fundada em bancos e atividades comerciais na região de Hannover.

${ }^{20} \mathrm{Q}$ uanto ao vínculo nacionalista disseminado entre os seguidores de Usener, ver S. Weigel: $1995,141$.

${ }^{21}$ Assim escreveu Mann, numa carta a Hermann Hesse, após o desfecho da Segunda Guerra: "Penso que nenhum vivente pode, hoje, esquivar-se do político. Uma recusa também é uma decisão política, mas em favor da causa errada" [apud W. H. Bruford: 1975, 255]. 
${ }^{22}$ Carlo Ginzburg [1966: 48-9] assinala que F. Saxl não dava tanta atenção aos pressupostos teóricos e conceituais de Warburg, preferindo insistir "nos resultados concretos obtidos pelo estudioso hamburgês".

${ }^{23}$ Ver tabela em anexo.

${ }^{24}$ Poucos anos antes do genocídio ainda havia uma União dos Judeus Nacional-Alemães; a Liga de Amigos Combatentes Judeus participava regularmente das cerimônias de louvor à bandeira nacional da Alemanha; $c f$. L. Richard: 1983, 147.

${ }^{25}$ É interessante o contraste entre essa imagem (lembrando o "enxerto" vegetal) e a dinâmica "assimilação" dos judeus à cultura alemã, até a ascensão do nazismo.

${ }^{26}$ W. S. Heckscher relembra uma engraçada boutade de Panofsky sobre William Blake: "Não agüento! Tudo bem se um sujeito é realmente doido, como Hölderlin; a verdadeira loucura até que produz flores poéticas. Mas não suporto gênios enlouquecidos que passam a vida caminhando à beira do abismo. Blake é muito negativo e nada confiável” [apud W. S. Heckscher: 1993, 173].

\section{Bibliografia}

Assmann, Aleida [1993]. Construction de la mémoire nationale. Une brève histoire de l'idée allemande de Bildung. Paris: Maison des Sciences de l'Homme, 1994.

Assmann, Jan [1995]. “Collective Memory and Cultural Identity”. In: New German Critique 65. Ithaca: Cornell University, primavera/verão de 1995, pp. $125-133$.

Bruford, W. H. [1975]. The German Tradition of Self-cultivation. 'Bildung' from Humboldt to Thomas Mann. Londres: Cambridge University Press.

Calvino, Italo [1985]. Seis propostas para o próximo milênio. São Paulo: Cia. das Letras, 1990.

Diers, Michael [1995]. "Warburg and the Warburgian Tradition of Cultural History”. In: New German Critique 65. Ithaca: Cornell University, primavera/verão de 1995, pp. 59-73.

Frangenberg, Thomas [1979]. "Posfácio". In: E. Panofsky. Arquitetura gótica e escolástica. (q. v.), pp. 111-132.

Gay, Peter [1968]. A cultura de Weimar. Rio de Janeiro: Paz \& Terra, 1978.

Ginzburg, Carlo [1966]. "De A. Warburg a E. H. Gombrich. Notas sobre um problema de método". In: Mitos, emblemas, sinais. Morfologia e história. São Paulo: Cia. das Letras, 1990, pp. 41-93. 
Gombrich, E. H. [1963]. Meditations on a Hobby Horse and other Essays on the Theory of Art. Londres: Phaidon. [1972]. "Aims and limits of Iconology". In: The Essential Gombrich. Selected Writings on Art and Culture. Londres: Phaidon, 1996, pp. 457-484.

Gumbrecht, Hans Ulrich [1994]. "A Farewell to Interpretation”. In: H. U. Gumbrecht e K. Ludwig Pfeiffer (orgs.). Materialities of Communication. Stanford: Stanford University Press, pp. 389-402.

Hart, Joan [1993]. "Erwin Panofsky and Karl Mannheim: A Dialogue on Interpretation". In: Critical Inquiry 19. Chicago, primavera de 1993, pp. 534-566.

Heckscher, William S. [1993]. "Erwin Panofsky: A Curriculum Vitae”. In: E. Panofsky. Three Essays on Style. Cambridge MA: MIT, 1995, pp. 169-197. Klibansky, Raymond, Erwin Panofsky e Fritz Saxl [1964]. Saturne et la mélancolie. Études historiques et philosophiques: nature, religion, médecine et art. Paris: Gallimard, 1989.

Leroux, Georges [1998]. "Préface". In: R. Klibansky. Le Philosophe et la mémoire du siècle. Entretiens avec Georges Leroux. Paris: Belles Lettres, 1998; transcrição eletrônica integral em < http://www.gallimard-mtl.com/klibans.htm >. Moxey, Keith [1995]. "Perspective, Panofsky and the Philosophy of History". In: New Literary History 26. Johns Hopkins University, pp. 775-786.

Neiva, Eduardo [1993]. “Imagem, história e semiótica”. In: Anais do Museu Paulista 1, nova série. São Paulo, 1993, pp. 11-29.

Panofsky, Erwin [1920-1]. "Albrecht Dürer e a Antigüidade clássica”. In: E. Panofsky. O significado nas artes visuais. São Paulo: Perspectiva, 1976, pp. 307-376.

[1932] "Contribution au problème de la description d'oeuvres appartenant aux arts plastiques et à celui de l'interprétation de leur contenu”. In: E. Panofsky. La perspective comme forme symbolique et autres essais. Paris: Éditions de Minuit, 1975, pp. 235-255.

[1939]. "Introductory". In: Studies in Iconology. Humanistic Themes in the Art of the Renaissance. Nova York: Icon, 1995, pp. 3-31.

University Press, 1971. 
[1951]. Arquitetura gótica e escolástica. Sobre a analogia entre arte, filosofia e teologia na Idade Média. São Paulo: Martins Fontes, 1991. [1953]. "Três décadas de história da arte nos Estados Unidos. Impressōes de um europeu transplantado”. In: E. Panofsky. O significado nas artes visuais..., pp. 411-439.

[1955]. "Iconografia e iconologia. Uma introdução ao estudo da arte na Renascença”. In: E. Panofsky. O significado nas artes visuais, pp. 47-87.

Richard, Lionel [1983]. A República de Weimar (1919-1933). São Paulo: Cia. das Letras, 1988.

Saxl, Fritz [1927-8]. "Macrocosmos y microcosmos en las pinturas medievales". In: F. Saxl. La vida de las imágenes. Estudios iconográficos sobre el arte occidental. Madri: Alianza, 1989, pp. 59-71.

[1929-30]. “La visita de Warburg a Nuevo Méjico”. In: F. Saxl. La vida de las imágenes..., pp. 290-295.

[1944]. “Tres 'florentinos': Herbert Horne, A. Warburg y Jacques Mesnil”. In: F. Saxl. La vida de las imágenes..., pp. 296-307.

Warburg, Aby [1905]. “Albert Dürer et l'Antiquité italienne”. In: A. Warburg. Essais florentins. Paris: Klincksieck, 1990, pp. 159-165.

[1920]. "La Divination païenne et antique dans les écrits et les images à l'époque de Luther”. In: A. Warburg. Essais florentins, pp. 245294.

[1923]. Il rituale del serpente. Una relazione di viaggio (Immagine dalla regione degli indiani Pueblo del Nordamerica. Milão: Adelphi, 2001. [1923a]. Carta a Fritz Saxl datada de "Kreuzlingen, 26 de abril de 1926”. In: A. Warburg. Il rituale del serpente. Milão: Adelphi, 2001, pp. 67-8.

Weigel, Sigrid [1995]. "Aby Warburg's 'Schlangenritual': Reading Culture and Reading Written Texts”. In: New German Critique 65. Ithaca: Cornell University, primavera/verão de 1995, pp. 135-153.

Yates, Frances A. [1964]. Giordano Bruno and the Hermetic Tradition. Chicago: The University of Chicago Press, 1991. 


\section{Anexos}

\section{Tabela sobre os niveis da melancolia}

\begin{tabular}{|c|c|c|c|c|}
\hline Nível & Instrumentos & $\begin{array}{c}\text { Hábitat } \\
\text { psicológico }\end{array}$ & $\begin{array}{l}\text { Domínio de } \\
\text { realização criadora }\end{array}$ & $\begin{array}{l}\text { Domínio da } \\
\text { profecia }\end{array}$ \\
\hline I & $\begin{array}{l}\text { Espíritos } \\
\text { inferiores }\end{array}$ & Imaginatio & $\begin{array}{l}\text { Artes mecânicas, } \\
\text { notadamente } \\
\text { a arquitetura, } \\
\text { a pintura etc. }\end{array}$ & $\begin{array}{l}\text { Eventos naturais, } \\
\text { enchentes, } \\
\text { fomes etc. }\end{array}$ \\
\hline II & $\begin{array}{l}\text { Espíritos } \\
\text { medianos }\end{array}$ & Ratio & $\begin{array}{l}\text { Conhecimento } \\
\text { dos seres naturais } \\
\text { e humanos, ciências } \\
\text { naturais, medicina, } \\
\text { política etc. }\end{array}$ & $\begin{array}{l}\text { Eventos políticos, } \\
\text { deposição de } \\
\text { soberanos, } \\
\text { restaurações etc. }\end{array}$ \\
\hline III & $\begin{array}{l}\text { Espíritos } \\
\text { superiores }\end{array}$ & Mens & $\begin{array}{l}\text { Conhecimento dos } \\
\text { segredos divinos, } \\
\text { notadamente a } \\
\text { cognição da lei } \\
\text { divina, angeologia } \\
\text { e teologia }\end{array}$ & $\begin{array}{l}\text { Eventos religiosos, } \\
\text { aparição de novos } \\
\text { profetas ou o } \\
\text { surgimento de } \\
\text { novas religiões }\end{array}$ \\
\hline
\end{tabular}

Fonte: Klibansky et al.: 1964, 566 
$172 \cdot$ Tоро I

2. Figura I: S. Jerônimo em seu estúdio. A. Dürer (gravura).

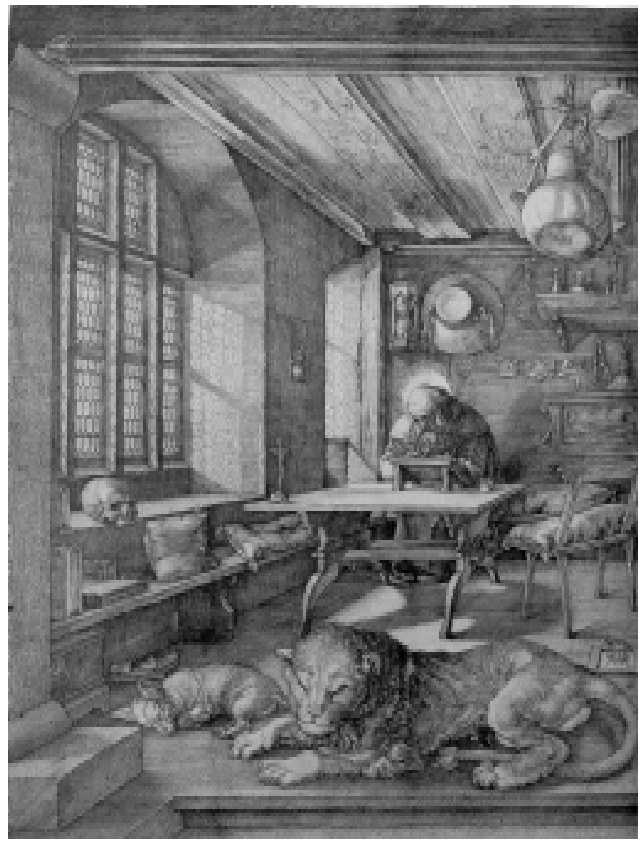

3. Figura II: E. Panofsky em seu escritório em Hamburgo. Autor anônimo (fotografia).

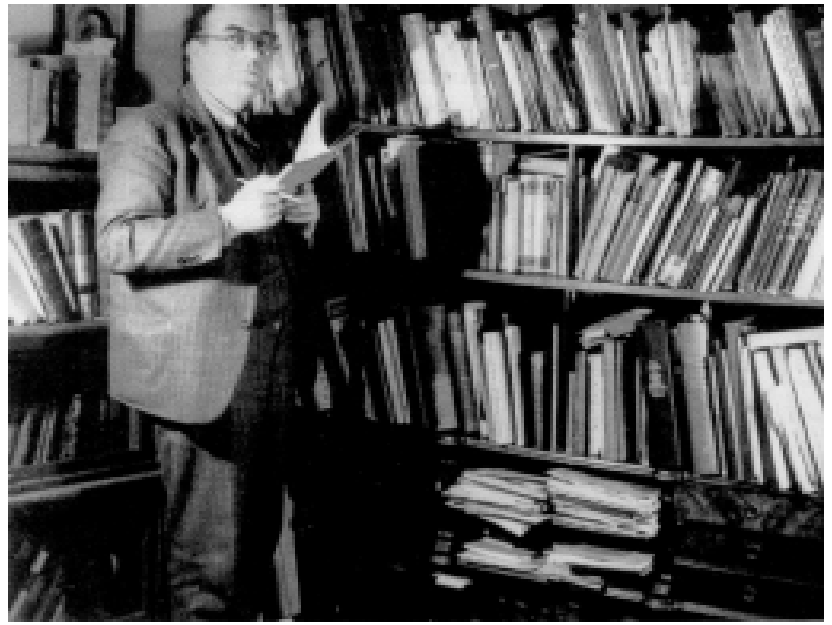




\section{Resumo}

Ao ser publicado, na Inglaterra, em 1964, o livro Saturno e a melancolia perdera os referenciais históricos e culturais que marcaram sua versão embrionária, na Hamburgo da década de 1920. As turbulências do século XX levaram à obsolescência um aspecto decisivo do projeto inicial: o realce, através da obra de Albrecht Dürer, da contribuição da Alemanha ao ideal renascentista do homem superior e temperamental, numa prefiguração do conceito romântico de "gênio". Os autores, judeus assimilacionistas, começaram o trabalho quando a crise da República de Weimar coincidia com a internação num hospital psiquiátrico de seu patrono intelectual, o historiador da arte Aby Warburg. A ascensão do nazismo os dispersou e eles se afastaram cada vez mais da figura e das idéias de Warburg.

\section{Abstract}

When it was published in England in 1964, the book Saturn and Melancholy had lost the historical and cultural references that have framed its original version, in the Hamburg of the 1920's. The turmoil of the $20^{\text {th }}$ Century led to obsolescence one of its main scopes: the focus on the German contribution, with Albrecht Dürer's work, to the Renaissance ideal of the temperamental, superior man, as a forerunner of the romantic concept of "genius". The authors, assimilacionist Jews, had begun their work while the Weimar Republic was starting to collapse, just as their intellectual patron, the art historian Aby Warburg, retired to a psychiatric hospital. The rise of Nazism scattered them and they increasingly moved away from Warburg's character and ideas. 